\title{
Knowlton Circles: A Later Neolithic and Early Bronze Age Ceremonial Complex and its Environs - a review
}

\author{
John Gale ${ }^{1}$ \\ Department of Archaeology, Anthropology \& Forensic Sciences, Bournemouth University, \\ UK
}

N.B. This copy is the Author's Original Manuscript accepted for publication (postprint). The Version of Record of this manuscript has been published and is available in:

Landscapes vol 18 issue 2 published online 22 Feb 2018

https://doi.org/10.1080/14662035.2018.1429715

\footnotetext{
${ }^{1}$ Contact: John Gale; jgale@bmth.ac.uk; Department of Archaeology, Anthropology and Forensic Sciences, Bournemouth University
} 


\title{
Knowlton Circles: A Later Neolithic and Early Bronze Age Ceremonial Complex and its Environs - a review
}

\author{
John Gale ${ }^{2}$ \\ Department of Archaeology, Anthropology \& Forensic Sciences, Bournemouth University, \\ UK
}

\begin{abstract}
The larger henge monuments of Wessex have been the focus of detailed archaeological investigation for over a century and consequently their study has provided a greater, albeit fragmentary, understanding of later Neolithic society. For the most part such studies have continued to show that these great mega-structures of the $3^{\text {rd }}$ millennium BC persist as beacons of ceremonial functionality into which later societies invested much of themselves, intellectually, spiritually and unquestionably physically. While Stonehenge, Avebury and Durrington Walls continue to attract a great deal of attention with on-going research, comparable sites in Dorset have been less well researched. Two campaigns of archaeological investigation undertaken in the Allen Valley of east Dorset by the author have focussed upon the complex of earthworks at Knowlton and additionally at one of three broadly contemporary barrow cemeteries located nearby. The findings from these investigations are beginning to shed more light on the possible origins and development of these important but weakly understood landscapes. This paper outlines some of the main findings from these investigations and posits a chronological framework for the integration of a group of monuments that formed both a ceremonial landscape and a geographical and spiritual home for communities that lasted for a thousand years.
\end{abstract}

Keywords Early Bronze Age; Neolithic; henge; mortuary enclosure; round barrow; beaker house; dolines.

\section{Introduction}

The henge monuments of the British Isles still represent a rather enigmatic and loose collection of earthworks for the most part considered to date to the latter half of the $3^{\text {rd }}$ millennium B.C. Recent work on some of the larger henges in the south of England, most notably at Durrington Walls, Wiltshire (Parker Pearson 2007; 2012) have revealed some insights into pre-henge activity and settlement, but still the overarching interpretation of their utility is limited to a poorly defined yet enduring banner of 'ceremonial' activity.

In this paper the focus is on the Knowlton Complex, located in the upper Allen valley of east Dorset. It includes not only the cluster of henges or henge-related monuments located

\footnotetext{
${ }^{2}$ Contact: John Gale; jgale@bmth.ac.uk; Department of Archaeology, Anthropology and Forensic Sciences, Bournemouth University
} 
there, but also an abundance of funerary monuments found in close association (Figure 1). In addition to the examination of the potential cultural associations between these monuments, consideration will also be given towards possible associations with components of the local natural landscape, with which they may all have been inextricably linked.

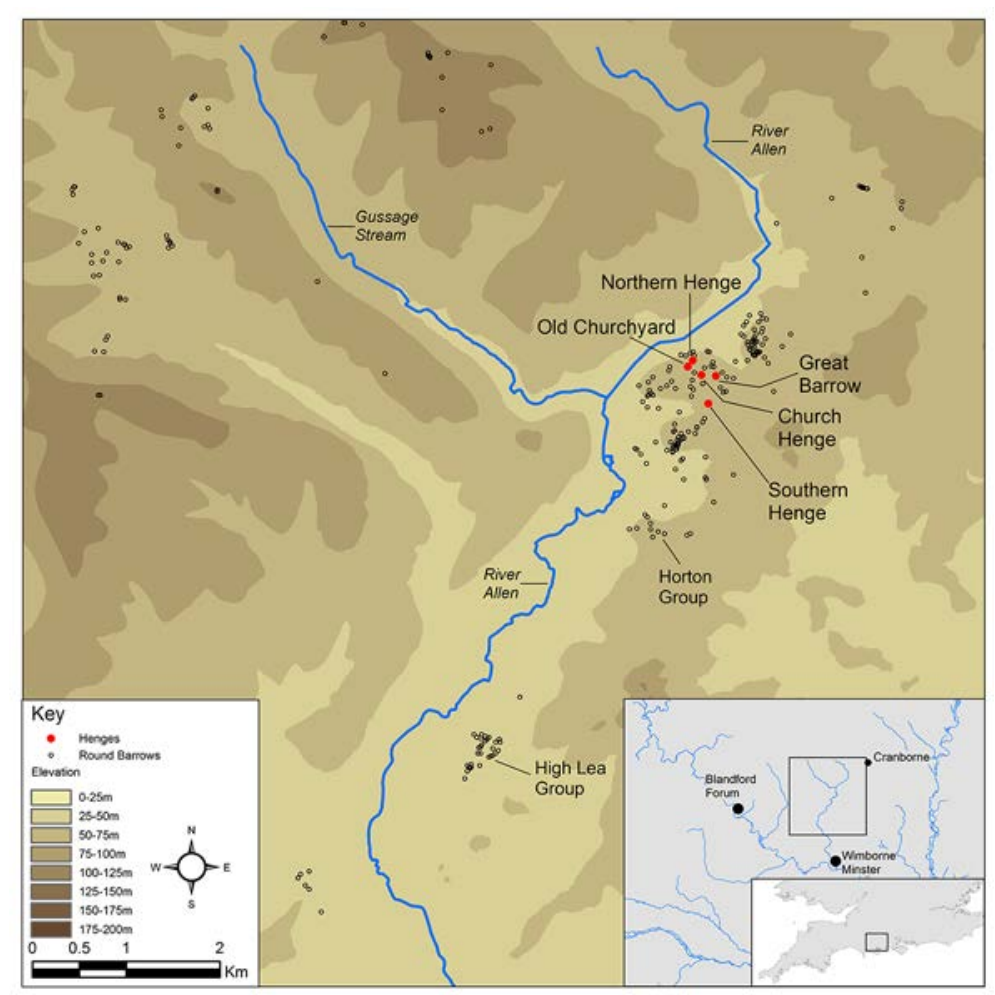

Figure 1 Location map of the henge complex at Knowlton and its associated round barrows (ring ditches) in the Allen Valley, east Dorset.

In considering these monuments within a culturally evolving landscape, it is possible that the group had a potential collective use for up to 1000 years. Such an extended period of apparent continuity in the choice of place requires us to consider the complex dynamics of social and religious change experienced by the successive communities of people who had cause to build, adapt and utilise the monuments, whilst also accepting the underlying continuity provided by a sense of place frequently found in human societies. That such a complex dynamic would be expressed or have impacted upon the design, use and adaptation of the monuments over time is of course highly likely. Such changes are not necessarily easily identifiable in the surviving archaeological remains but may nonetheless be inferred or at the very least tentatively suggested from observable variations in form, size, orientation etc. Recent field-work directed by the author has led to the formulation of a larger data set on this collective group of late Neolithic and early Bronze Age monuments, the principle elements and potential sequencing of which are outlined below.

Two campaigns of excavation and field survey (1993-7; 2002-8) were undertaken in the vicinity of the henge complex, the former at the henge complex itself, with a further programme of work at one of the group of barrow cemeteries (High Lea Farm) found in the same river valley (Gale et al 2008; Gale 2012). The results from these investigations indicate that whatever these mega-structures at Knowlton represented at the time or times of their first 
construction, they later evolved to become major focal centres for the establishment of funerary complexes and landscapes where the presence and actions of previous occupants would be adopted, adapted or overwritten in a sequence of structured depositions. The landscape and monuments at Knowlton consequently must be considered as both evolutionary and dynamic; in which underlying meaning or intent is more likely to evolve as the successive builders and users engaged with it.

Such a reflexive approach to planning was put forward by John Barrett on the enclosure and stone circles at Avebury. Here he developed an earlier idea by Evans of ongoing or abandoned projects undertaken in localised places by people who are unlikely to have lived to have seen the totality of their creative efforts. (Barrett, 1994, 13-14; Evans, 1988, 85-96). Such an interpretation may equally apply at Knowlton and may have continued well into the $2^{\text {nd }}$ millennium and almost certainly beyond, although a detailed sequence must await a more progressive and intrusive dating campaign. Within this schema of progressive adaptation, however, there is found at Knowlton recurring elements suggestive of their attempts to link their world to a greater cosmological order.

The theme of later Neolithic and early Bronze Age communities having conceptualised landscapes for their ancestors is not new and has been postulated before, most particularly for the Stonehenge area (Darvill 1997; Parker Pearson \& Ramilisonina 1998). But it could also be inferred elsewhere from the tendency of other henge monuments to attract later Beaker burials and clusters of round barrows i.e. Stanton Harcourt (Barclay et al. 1995), and Dorchester on Thames (Smith et al. 1997) amongst others. Such approaches to the understanding of prehistoric landscapes does however have its critics, notable amongst whom was James Whitley, who argued that in contemporary archaeological interpretation '..they (the ancestors) are being asked to do too much' $(2002,119)$ in respect of an overarching causality behind the continuous re-use of monuments and landscapes. Rather than casually using the term ancestors, therefore, this paper relies on a more neutral approach to describe linkage between successive occupiers of a shared location who may indeed share familial ancestry but for whom the more important factor is their reaffirmation of the use of a particular place. The activities and practices marked by the material culture of successive occupiers, however, may well be quite different. Details on the mechanisms, circumstances and durability of the relationship between locations and their occupiers are poorly understood, however, and by no means necessarily or universally transferable across sites and landscapes in which henges and barrows are found. For the moment however, inter and intrasite site comparisons are essential to improve the interpretation of groups of monuments.

\section{The Knowlton Complex}




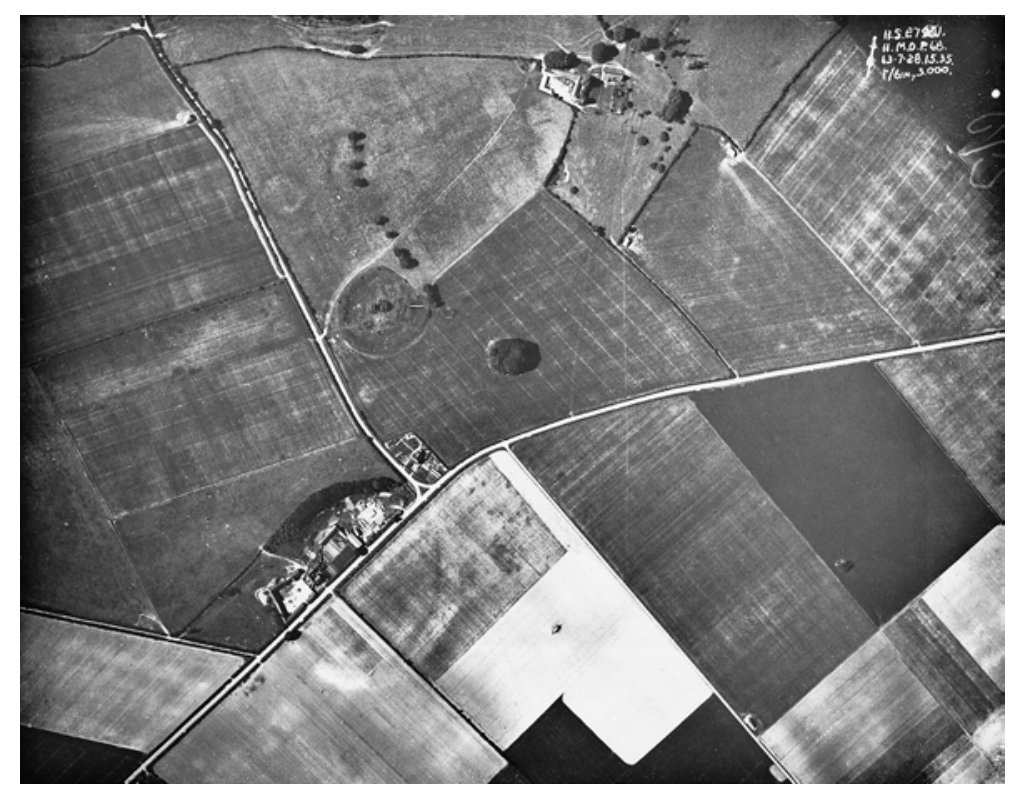

Figure 2 Vertical aerial photograph of the Knowlton Complex taken in 1928, with the Central or Church henge and the Great Barrow showing clearly as upstanding earthworks towards the centre of the photograph. Also showing are the crop marks of the 'Old Churchyard', Northern henge (both above the Church henge) and the much larger southern henge (below the Church henge). (c) Historic England Archive (Crawford Collection).

Knowlton Circles, Knowlton Rings or the Knowlton Henge Complex, as it is variously known, is unusual in that no one quite agrees as to the definition and classification of the sum of its parts. Certainly it contains five large 'circular' earthworks: the Southern Circle, the Church or Central Circle, the Northern or 'D' shaped enclosure, the 'Old Church Yard' and the Great Barrow (Figure 2). Are they all henges? Three of them seem to fit the generally recognised definition of a henge, each comprising of a circular earthwork consisting of a ditch with an external bank (the Southern, Northern and Central monuments).

The remaining two principal monuments of the group are not so easily interpreted. The Great Barrow may or may not be a later Neolithic Round Barrow unified within a henge- 


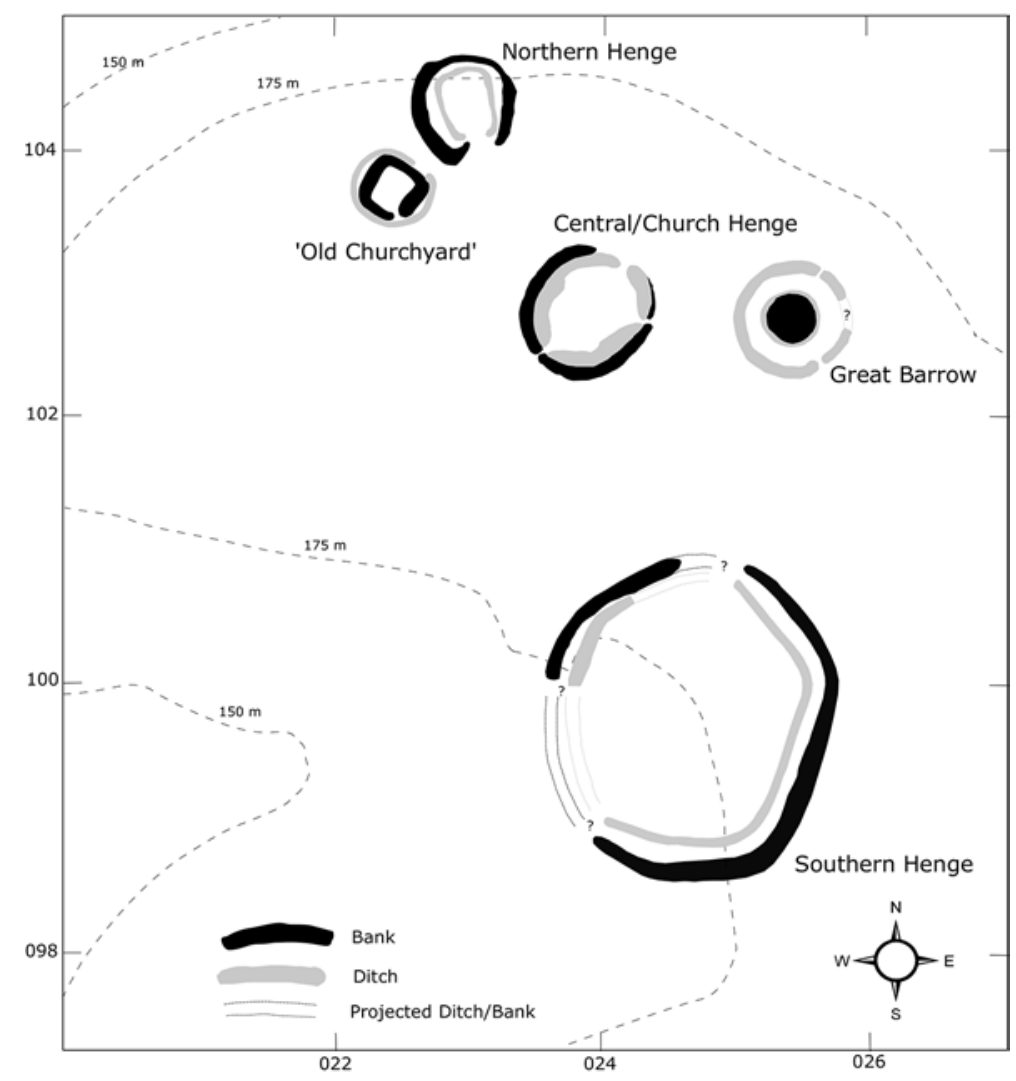

Figure 3 Schematic plan of the five enclosures that form the Knowlton complex.

like monument of a broadly comparable date and time. The 'Old Church Yard' has never been definitively linked to the Medieval Church that was later constructed inside the Central Circle, and whilst demonstrably having an external ditch/internal bank arrangement it should not be summarily dismissed as being unrelated to the Neolithic henge complex.

Before going into detail about the individual attributes of each of these separate earthworks, what is abundantly clear is that they are marked by their individual distinctiveness. Their shape and size bear little comparison with each other, which is at odds with other broadly comparable well known large henge clusters; the best example of which is Thornborough, Yorkshire (Harding 2000; 2003). There the three henges have a greater degree of morphological similarity, and would therefore seem to share a commonality of design that may mirror a shared ancestry and purpose. In contrast, the marked diversity in form exhibited by the enclosures at Knowlton may indicate that they were conceived or designed separately and constructed in a progressive sequence, possibly over an extended time scale, as yet to be defined. Such variance in form and size could of course also reflect variability in function whilst still maintaining cohesion through a shared location. It is of course entirely possible that all may have been in use at a particular point in time forming a 'precinct' of distinctive but nonetheless linked elements where communities gathered periodically in the observance of rites or activities focused on a specific enclosure. With the exception of a single radiocarbon date from the Southern Circle (Beta 141096, $3890+/-60$ BP [2570-2190 cal. BC 2 sigma]), dating of the enclosures remains ill-defined and consequently problematic. However, recent surveys have provided sufficient detail to allow for the construction of a speculative sequence. 
The growing body of evidence in support of a 'formative' phase of henge monument construction (Harding 1987, 59) is now generally accepted, drawing upon aspects of commonality in structural form with earlier Neolithic monuments. Ideas promulgated in the 1950s and 1960s from such luminaries as Isobel Smith and Gordon Childe concerning the development of henges from the earlier causewayed enclosures have re-emerged and have support in some areas (Darvill 2010, 152). The discovery of segmented ditched enclosures such as those at Flagstones in Dorchester, Dorset (Healy 1997, 27-47) dating to the close of the $4^{\text {th }}$ millennium seem to parallel developments seen at Stonehenge I (Darvill 2006, 97) and at least superficially bear a striking similarity to the constructional technique adopted for the earlier causewayed enclosures. These segmented enclosures seem to be commonly linked to burial and funerary practices and, along with the occurrence of similarly early dated enclosures at Balfarg, (Barclay \& Russell-White 1993) Llandegai A (Houlder 1968; Lynch \& Musson 2001) and Dorchester Site 2 (Whittle et al 1992), indicate enclosure forms that predate the 'classic' henge forms that emerged in the middle of the $3^{\text {rd }}$ millennium.

The adoption of the term 'formative henge' in the archaeological literature (Harding 2003, Darvill 2010, Burrow 2012) could be usefully broadened and applied to two and possibly three of the Knowlton enclosures - the Northern Circle, the Old Churchyard and the Great Barrow - although each is very different from the others in plan form. The Northern Circle consists of an open-ended 'D' shaped plan with an external bank. If it were not for the external bank the plan would look remarkably similar to the plan form of earlier long barrow forms and mortuary enclosures but this must surely be too superficial and circumstantial to imply a common ancestry. Its design therefore remains unique among henge monuments, the concept behind which remains for the moment unknown. The 'Old Churchyard' also has a markedly different plan form, consisting of a circular external ditch whose internal bank is sub-rectangular. The name of this enclosure would seem to imply a medieval or later date but this is unproven. There is no contemporary historical reference to the monument having been used for Christian burial, rather that its use is inferred from its proximity to the Church. Its close proximity, state of preservation and likely integration with the other monuments in the prehistoric complex would seem grounds enough to support its contemporaneity, but this can only ultimately be confirmed through excavation. Its closest parallel is probably to be found in Llandegai A, excavated by Houlder in 1967-8 (Houlder 1968; Lynch \& Musson 2001) where a close association with funerary practice is demonstrated.

The credentials of the Southern and Central Circles are much more secure with both having 'classic' henge forms. A more refined classification using the archetypal scheme originally defined by Atkinson et al (1951) cannot be achieved due to the nature and extent of damage that has occurred on the monuments since they went out of use. Atkinson's classification scheme largely relies upon the identification of entrances, but at both these enclosures the location of original entrances remains unclear. 


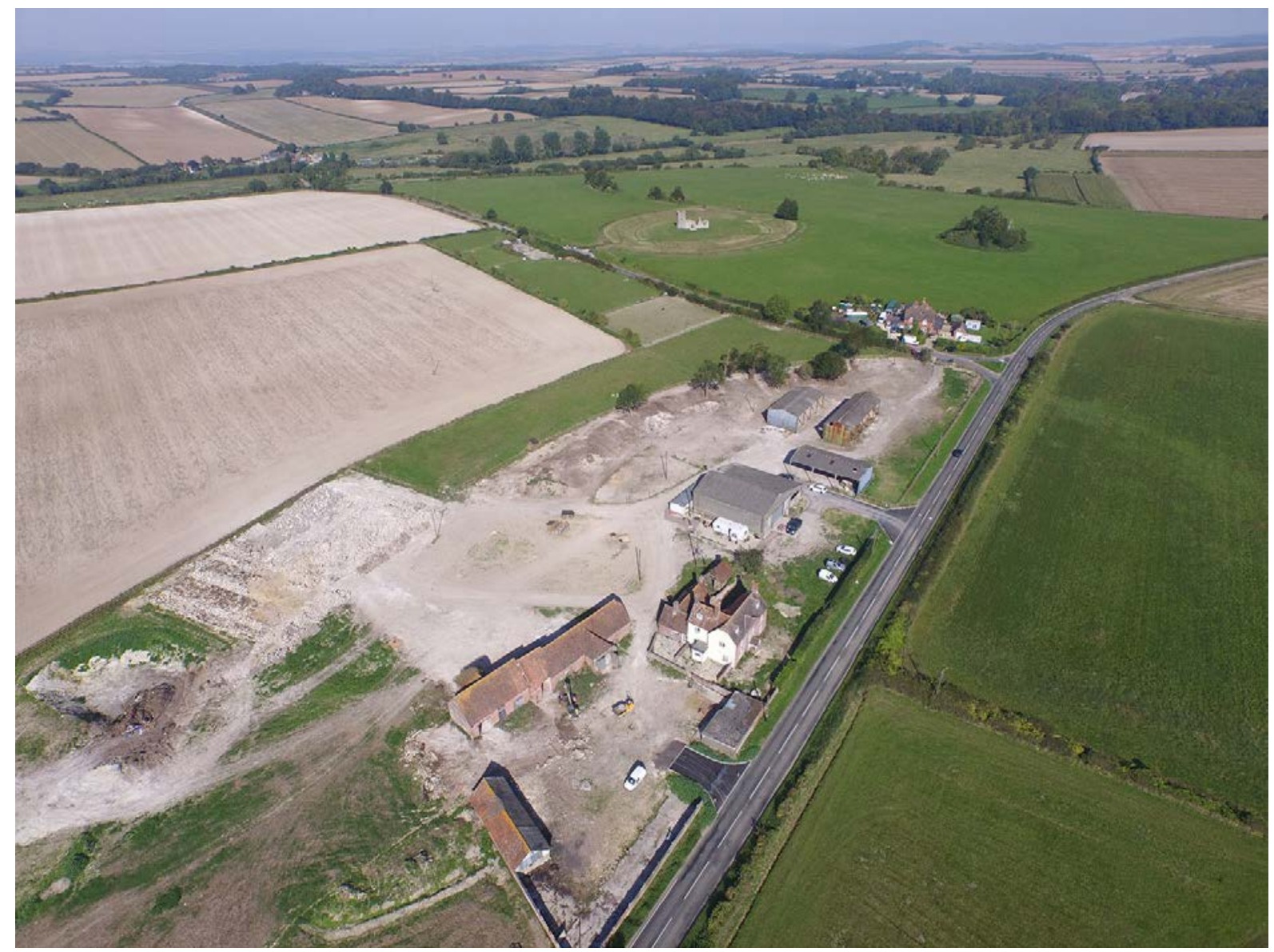

Figure 4 Low elevation oblique photograph from the south-east showing the arc of the surviving bank of the Southern Henge (in the centre of the picture) with the Church Henge and the Great Barrow in the background. (c) John Gale and Bournemouth University.

This is due to the marked and probably episodic reworking of the Central Henge to accommodate the later Church and its yard and the almost total loss of above ground elements of the Southern Circle through agricultural attrition and relatively recent groundworking and erection of farm buildings (Figure 4). The size of Knowlton's Southern Circle (approximately 240m in diameter - including the external banks) might lead to some consideration of its inclusion within that small group of 'super henges' or henge enclosures found within Wessex (Durrington Walls, Marden, Mount Pleasant and Avebury being the others). Its siting within a river valley also bears favourable comparison to the others. However, the lack of evidence for substantive internal features found at the others would seem to suggest, for the moment at least, that it remains interpreted as a very large 'classic' henge. This view is partially supported by excavations in 1994 which looked at a section through the bank and ditch (Figure 5) and failed to uncover any appreciable evidence for residual domestic or ritual activity that may have taken place within the enclosure (Gale in preparation). 


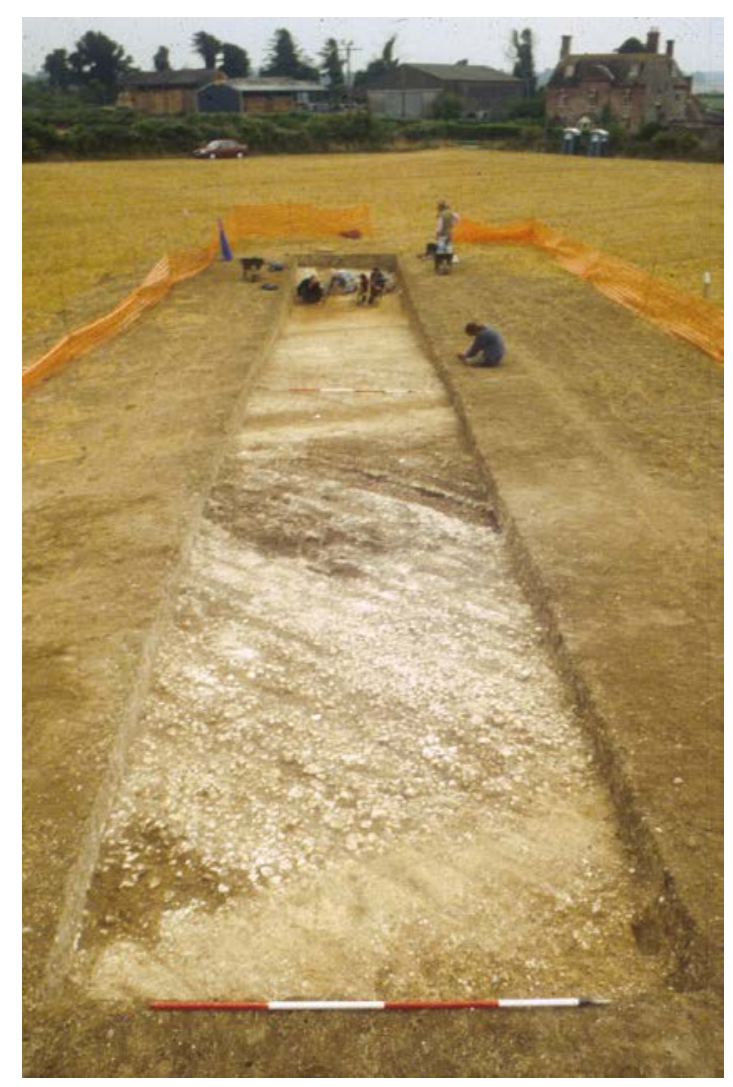

Figure 5 View of the 1994 excavation at the Southern Henge (south-east quadrant) taken from the south-east. The remnants of the henge bank and its underlying Neolithic ground surface can be seen in the foreground. (C) John Gale

The final enclosure to be considered here is the Great Barrow, which is contained within two concentric ditch circuits that may suggest the barrow was inserted within an earlier enclosure that may have been henge-related (Barber et al 2010, 155-8). Here the aerial photographic evidence suggests that the outer ditch may be at least partly segmented and the presence of an internal bank was tentatively confirmed through observations made during the excavation of a pipe trench in the summer of 1958 (Field 1962). Further investigations may reveal this to be of a form nominally related to the Flagstones enclosure in Dorchester, Dorset (Healy 1997), itself part of a cluster of later Neolithic ceremonial monuments found in close proximity to each other (Maumbury Rings, Mount Pleasant, Flagstones and the Dorchester post circle).

Why then should such monuments be clustered at this particular location? Let us assume that the choice of location is of primary significance and not therefore circumstantial or random. Choice of location for any human activity can be driven by cultural and/or noncultural factors. If so, is there any evidence for the presence of such determinants to be found in the current archaeological landscape? Evidence for the presence of pre-henge cultural activity in the area has mainly been confined to the results of archaeological sampling in the upper Allen valley where lithic scatters and environmental proxies suggest the presence of open grassland rendzina soils that may indicate land clearance as early as the later Mesolithic (French et al 2007, 131-97). The presence of earlier cultural activity that might help to 
account for the emergence of the building of large monuments and what was to emerge in the $3^{\text {rd }}$ millennium is certainly not evidenced in known archaeological structures or associated material. Episodic fieldwork by the author and others working in the Knowlton environs have failed to identify substantive structural evidence for pre-henge settlement. In contrast to the intensive nature for earlier Neolithic activity only a few miles to the north and west (Barrett et al 1999), it would seem that Knowlton, and its immediate environs were under-exploited when the henge builders first moved in. Therefore, it appears that the archaeological landscape contains few cultural proxies to account for why this particular locale was chosen and why it became such a centre of activity from the middle of the $3^{\text {rd }}$ millennia.

Examination of the non-henge components of the Knowlton complex shows that it is dominated by the presence of round barrows (or at least the remnant ring ditches that have survived) that would largely post-date the construction of the henges. An aerial survey undertaken in 2000 (Stoertz 2007, 40-3) established that within a $1.5 \mathrm{~km}$ radius of the complex there were 178 ring ditches, a density unsurpassed elsewhere in Wessex. Although it is impossible to be sure how long this cemetery was in use, it is apparent that it became a focus for burial activity and associated ceremonial rites and practices during the later stages of the development of the whole Knowlton complex. It is difficult to determine whether a focus on funerary structures was part of the original concept of the complex, but the presence of the Great Barrow, likely to be contemporary with the earlier phase of the complex, and possibly associated with the burial or memorial to someone of high status, perhaps gives us an indication that this may indeed be the case and led to the development of the area as a burial centre.

Nor is it the case that the cemeteries focussed directly around the henge complex existed in isolation.

\section{Further afield - the barrow groupings in the Allen Valley}

The Allen valley itself contains further clusters of barrows (Figure 1) with two distinctive concentrations to the south at the Holton Inn and at High Lea Farm (Gale 2012). As well as their relatively close proximity to the henge complex they also share spatial commonality with their articulation to the River Allen, in that they are all found on the eastern slopes of the river valley. A programme of field survey and excavation between 2002 and 2008 (Gale et al 2008), targeted at the largely levelled round barrow cemetery three miles south of Knowlton at High Lea Farm near the village of Witchampton, has produced evidence that sheds some light on settlement within the Allen valley that was broadly contemporaneous with later phases of the henge complex. 


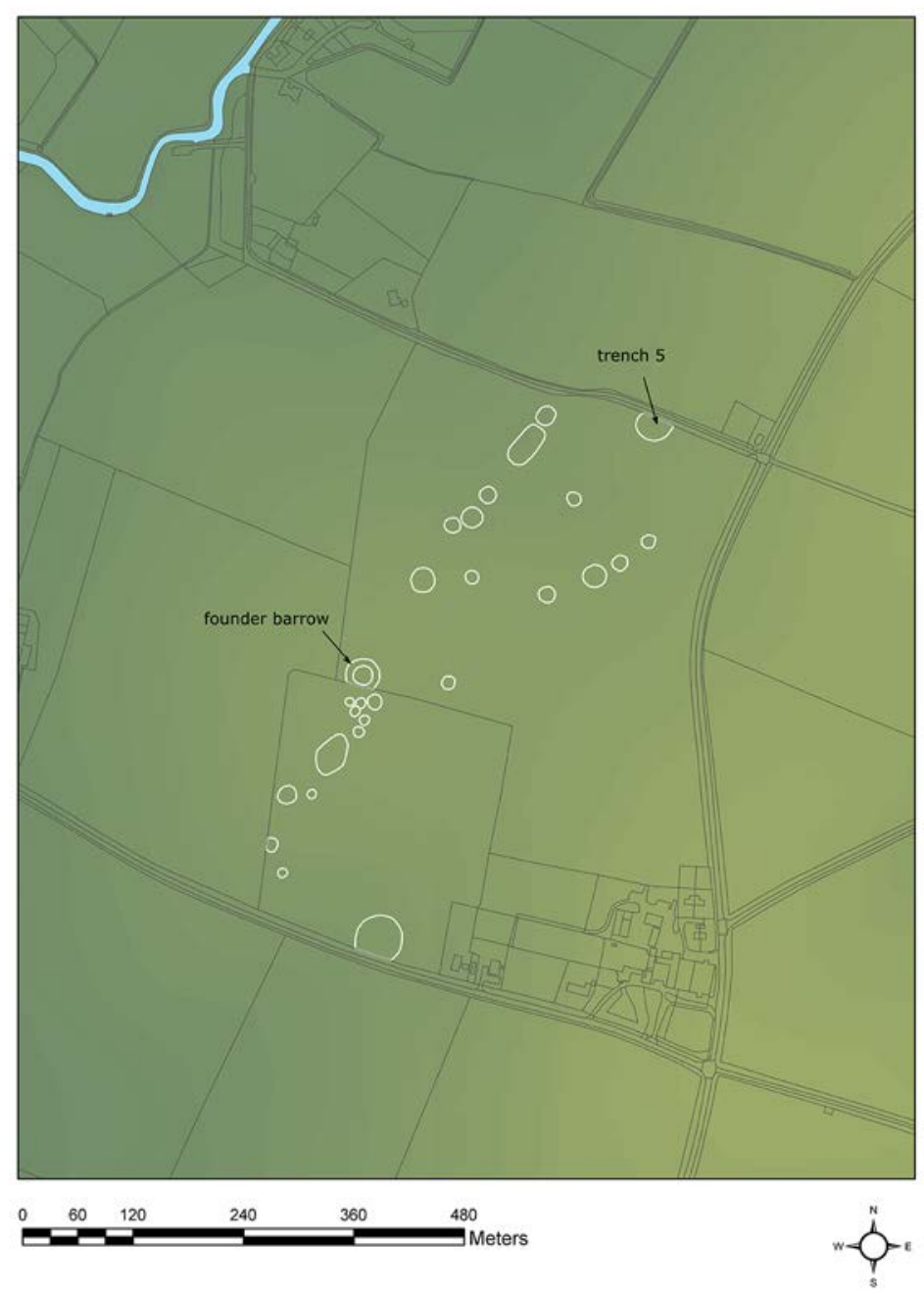

Figure 6. Plan of the High lea Farm Barrow group, located to the south of the Knowlton with the location of the 'founder' barrow and the site of the featured barrow (Trench 5) highlighted.

The cemetery at High Lea Farm consists of a triple linear alignment of over 30 barrows with attendant clusters mainly forming around an identifiable 'founder' barrow (Figure 6). Only two of the barrows remain as earthworks, the rest having been reduced to 'ring ditches' only visible via aerial photography and as geophysical phenomena when subjected to detailed investigation. Excavation of three of the ring ditches between 2003-5 (Gale et al 2006 and 2008) revealed the expected fragmentary and partial survival of cut features almost exclusively limited to the encircling ring ditches (Figure 7). Only a single secondary or satellite cremation survived from one of the levelled barrows, (UBA32501, 3360+/- 32 BP [1742-1709 cal. BC 2 sigma]) demonstrative of the high level of agricultural attrition and corresponding loss of archaeology in the group. In none of these sampled areas did a buried soil survive; coupled with the shallow depth of surviving ring ditches, the loss of chalk suggested that survival of inter-barrow archaeological deposits is unlikely unless activity penetrated deeply into the chalk. 


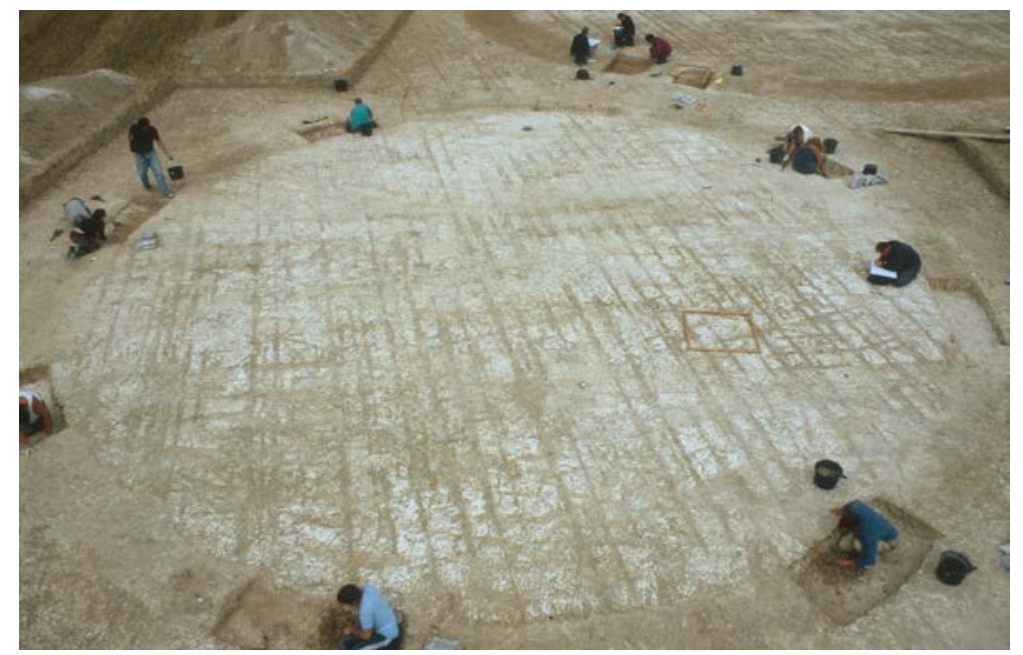

Figure 7 High Lea Farm Barrow Group excavation 2003 - 8. The ploughed out remains of these two barrows were explored during the 2003 season. Other than the encircling quarry ditch the only feature from the main barrow depicted here was the base of an urn containing a cremation (probably a satellite) which can be seen as a small dark spot near the top of the arc of the barrow ditch in the top centre of the photograph. (C) John Gale

The final excavation was targeted on the northernmost of the two visible monuments within the barrow group (Trench 5, see Figure 6). This barrow, as with the only other upstanding barrow in the group, lay within the headland of a field and accordingly had not been subjected to quite the same level of plough activity. The barrow was therefore potentially likely to present a higher level of surviving archaeological deposits which might shed some light not only upon the High Lea Farm group but by association those of other contemporary mounds within the valley, including those that developed around the Knowlton Henge Complex itself. The barrow did not disappoint and the excavations revealed a range of archaeological deposits that evidenced activity spanning over three millennia. Much of this activity goes beyond the bounds of this paper but some of it has a direct bearing on the henge complex to the north and accordingly may in part be linked to the building of the henges and ultimately to their incorporation into a funeral complex that may well have covered the major part of the river valley by the start of the $2^{\text {nd }}$ millennium.

The barrow's primary funerary deposit consisted of a centrally placed rectangular pit cut into the pre-barrow ground surface, in which had been placed two cremations within a rectangular frame made of wood (probably in the form of hurdling) that had neither a base nor a lid. Fragments of the frame have subsequently been radiocarbon dated to the early $2^{\text {nd }}$ millennium BC (UBA 18003, 3524+/- 38 BP [1948-1747cal. BC 2 sigma]). Preceding the interment of the two cremations an elaborate mortuary enclosure was constructed consisting of multiple concentric rings of stakes that were surrounded by irregularly placed pits (Figure 8). The innermost ring of stakes eventually had the rectangular pit excavated within it, in which the cremations were placed followed by the erection of a circular turf mound which spread up to the innermost of the two external stake circles. Later the surrounding ditch was excavated with the resultant chalk rubble placed on top of the turf mound but delimited by the outer ring of stakes. 


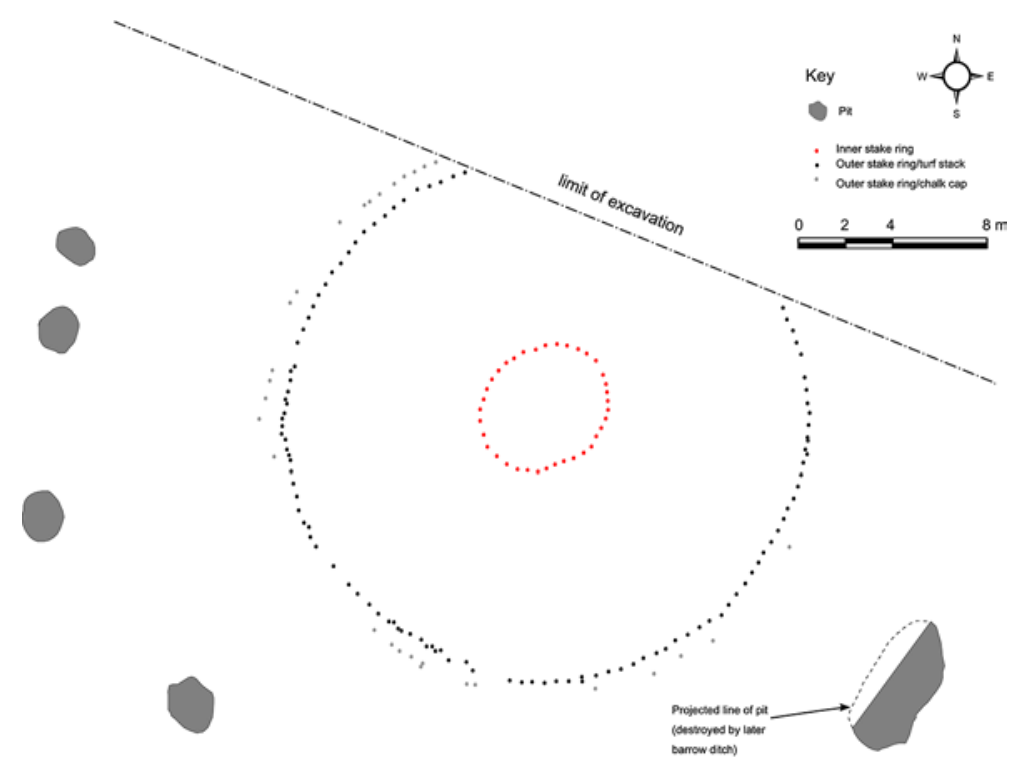

Figure 8 Plan of the excavated remains of an early $2^{\text {nd }}$ millennium BC mortuary enclosure found beneath a round barrow from the High Lea Farm Barrow Group (Trench 5).

The survival of the stake holes that formed this elaborate mortuary enclosure is of course attributable to the protection afforded by being covered by the later burial mound. The combination of pre-barrow features consisting of concentric rings of stakes and irregularly spaced pits are somewhat unique in the archaeological record although concentric stake circles themselves are rather more numerous (Ashbee 1960, 60-5; Woodward 2000, 25). What is most striking is that the rings of stakes clearly define a mortuary space that is integral to the design of the later barrow mound and therefore document not only the elements of the funerary process but also some rare structural detail on the associated monumentality. The question therefore is whether this feature is a rarity linked to the special status of those interred, or is its rarity an accident of survival. Was it more widespread in the communities that occupied the region and was practised in the cemeteries within the Allen valley?

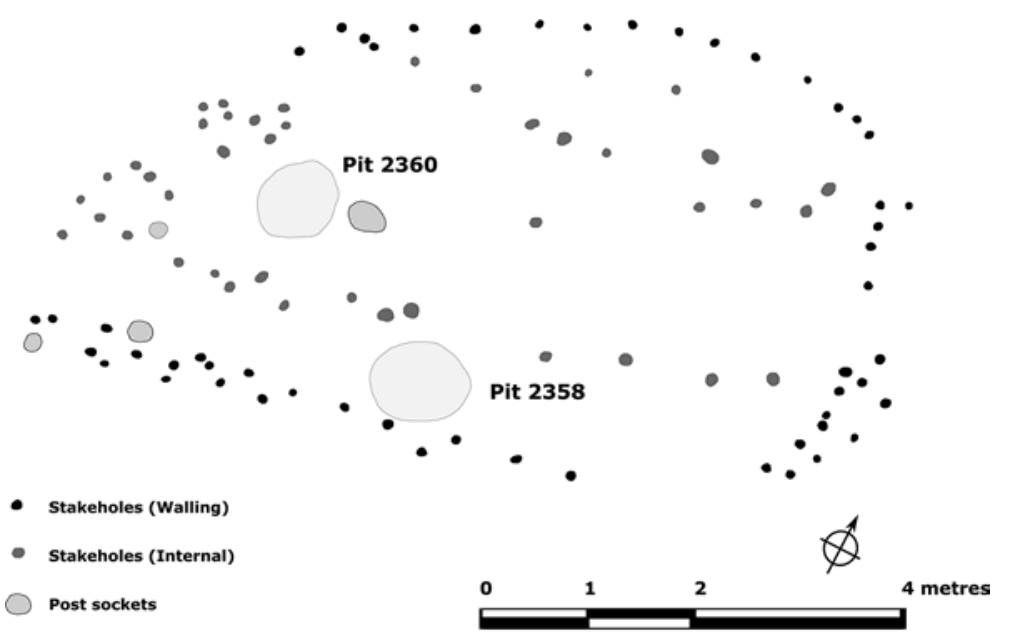


Figure 9 Plan of the excavated remains of a 'Beaker' period structure found beneath the mortuary enclosure and barrow from the High Lea Farm Barrow Group (Trench 5).

The mortuary enclosure was not the only evidence for pre-barrow activity at the site. Another sequence of stake holes was discovered underneath the barrow and slightly offset to the north-west of its centre. These stakes traced the plan of a roughly oval structure (possibly open ended on its western end) aligned on a WNW - ESE axis. The structure contained two straight-sided pits sunk to a depth of approximately $80 \mathrm{~cm}$ into the natural chalk, of a diameter of approximately $60 \mathrm{~cm}$. The structure also contained a number of internal stake-holes, some of which may have provided additional support for the superstructure of the building (Figure 9). The pits contained significant quantities of domestic waste including flint tools and broken ceramics of Beaker types contained within a matrix of burnt timbers and ash. This implies that the final function of the pits was as a receptacle for the clearance of the site which may well have included parts of the building itself. One of the pits contained a cache of flint nodules (un-burnt and weighing over $35 \mathrm{~kg}$ ) which would seem to be the stock of a flint knapper that for whatever reason was no longer of currency. A radiocarbon date from a sample of the burnt wood in one of the pits revealed a date from the second half of the $3^{\text {rd }}$ millennium BC (UBA 141096, 3850+/- 28 BP [2411-2270 cal. BC 2 sigma]) which not only predates the barrow and the mortuary enclosure by several centuries but also indicates that the structure is possibly contemporaneous with the Southern Circle at Knowlton, three miles to the north.

In addition, underneath the barrow in Trench 5 at High Lea there are further traces of two other possible structures, but only very partial arcs of a number of stake-holes survived, the rest having been destroyed by the later barrow ditch and by the loss of chalk in areas not protected by the barrow mound. Two further pits found less than $20 \mathrm{~m}$ from this Beaker house contained pottery (as did the turf stack within the burial mound) all of which would indicate the presence of at the very least a small community whom dwelt for a time in the vicinity of the Knowlton complex. Here at last then is some structural evidence for Beaker settlement within the valley that may be contemporaneous with that of communities who were probably actively engaging with the henges that will still have dominated the landscape at that time. That the settlement was superseded by a funerary site, is perhaps of no great surprise, given the potential passage of time between the two events but what is clear is that both episodes of activity took place within a landscape in which the henge complex was probably a major influence on communal activity.

The barrow cemetery at High Lea Farm, the cemeteries further upstream and the henges at Knowlton were all sited on the left, eastern, bank of the River Allen. Clearly therefore the river held some significance to the choice of location of them all, possibly unifying them all at some point in time. The henges' subsequent (and possibly original) use appears to be funerary in character and may consequently have been a ceremonial and monumental focus for a landscape for the dead (or perhaps more explicitly the ancestors) defined in part by the river. This idea is of course not new having been previously postulated by a number of academics for other similar Neolithic landscapes (Darvill, 1997; Parker Pearson \& Ramilisonina 1998) but is there any further evidence to support this? 


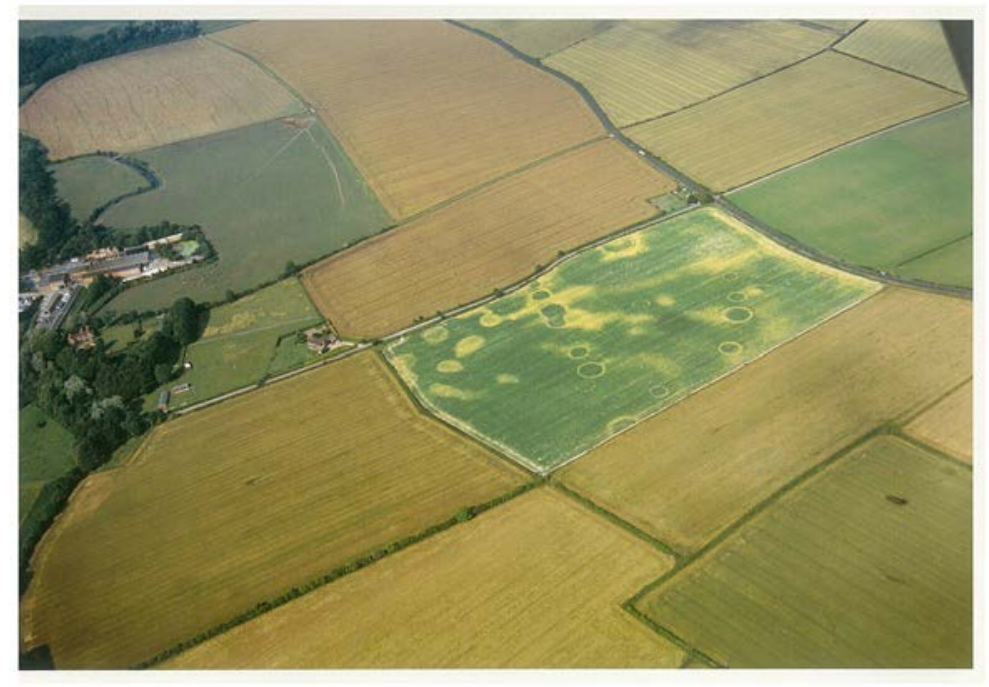

Figure 10 Oblique aerial photograph taken in 1989 of High Lea Farm Barrow Group. The ring-ditches show clearly in a crop of ripening pea as do the contrasting 'filled circles' of sink-holes nearby. (C) Crown Copyright. Historic England Archive.

An oblique aerial photograph of High Lea Farm taken in the 1980s (Figure 10) revealed crop marks of ring ditches alongside other circular and similarly sized features which were assumed to be potential pond barrows. Subsequent magnetometry surveys failed to detect them at all and it was only following the author's wider review of oblique photographs in the area that similar phenomena were noticed elsewhere in the river valley. Moreover, it was noticed that concentrations of these features were not only clustered on the eastern side of the river but were frequently found in association with the barrow cemeteries already mentioned. Further investigation has revealed these features to be entirely natural dolines (more commonly referred to as sink holes) that have completely filled up (possibly accelerated by the artificial sculpting and smoothing effects of repeated ploughing on the landscape in the last century and a half). A probable example of this type of geological feature (The Down Farm Shaft) was investigated nearby on Cranborne Chase by Martin Green in 1992. The excavation revealed a highly detailed and complex environmental sequence spanning the Mesolithic - Bronze Age periods (Allen 2000, 40-43). The linkage between barrows and sink-holes has been made before by Tilley (1994 and 1999) with reference to a similar occurrence of the co-location of barrows and sink holes on the South Dorset Ridgeway at Bronkham Hill near Dorchester and at several other locations nearby including Winterbourne Poor Lot barrow cemetery in West Dorset. However, in the Allen valley we see a striking pattern of such coincidence in the barrow cemeteries at High Lea Farm, the Holton Inn and at the henge complex itself with its extensive number of ring ditches surrounding the henges (Figure 11). The coincidence of sink holes with later Neolithic enclosures (and nearby round barrow cemeteries) has also been identified at Priddy Circles in Somerset which may suggest the practice was not isolated in the Allen valley or indeed Dorset (Lewis and Mullin, 2011). 


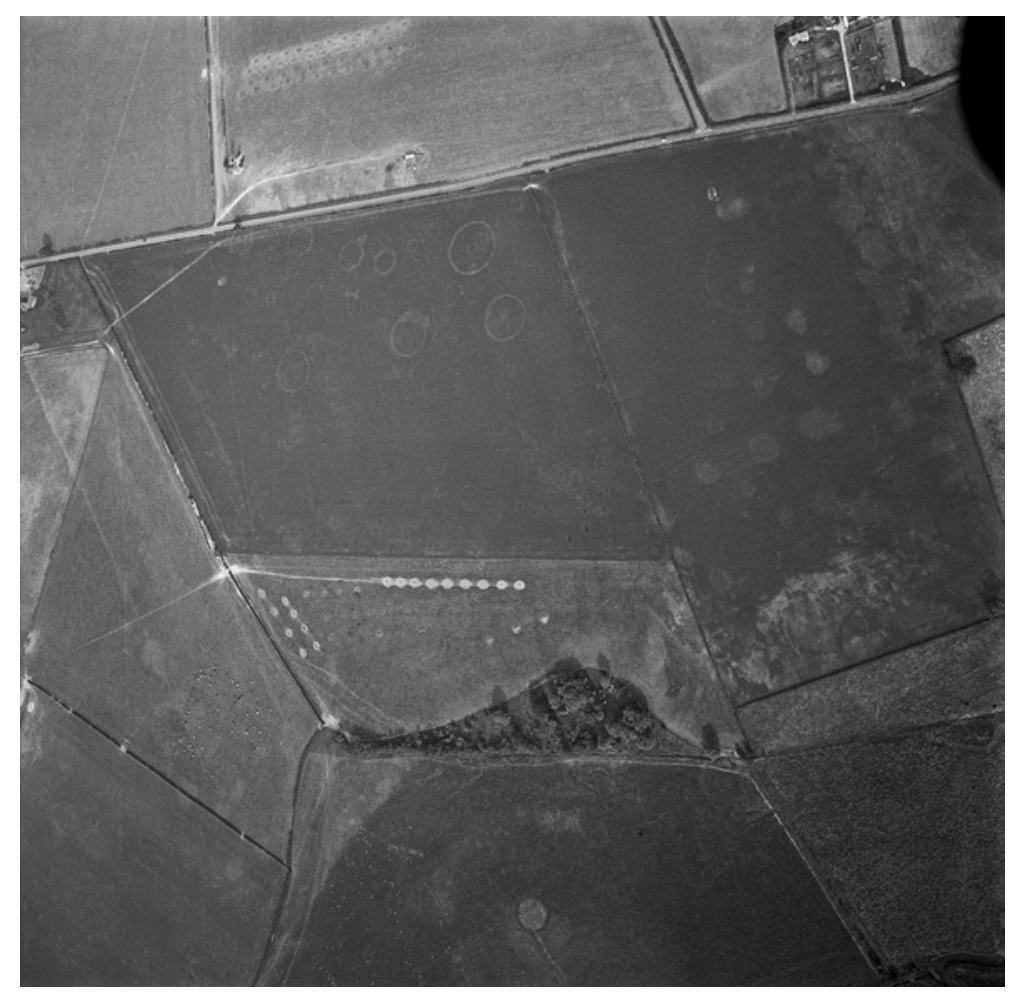

Figure 11 Aerial photograph of part of the southern extent of the barrow group surrounding the Knowlton complex. A cluster of ring-ditches can be clearly seen in the upper left quarter of the image with a cluster of sink holes located to the right of them. (C) Historic England Archive (Boyden Collection).

Were the builders of the complex at Knowlton complex aware of and influenced by the presence of the dolines? If so, dolines may have been one of the key factors in the siting of the henges and of the evolving funerary complex, and perhaps linked to a belief system sustained over a period of time. A belief system based upon a chthonic spirit underworld would require focal points for the two worlds to interact; voids in the earth may have held special significance in this regard. The importance of such natural places to ancient societies has been explored by Bradley (2000, 27-8) using case studies from classical Greece. Often in such cases natural places may be located away from the sphere of normal domestic life and may include springs and caves where the outer world of the living may commune with the depths. In the Allen Valley we therefore see the possible powerful combination of the River Allen and clusters of dolines that may have been incorporated into the contemporary cosmogony of local communities. The significance of water (Richards, 1996) and in particular the close association of henge monuments with river valleys, especially the larger henge enclosures of Wessex (Atkinson 1951, 84; Darvill 1997, 181; 2010, 154; Harding 2003, 54-6; Gale 2012, 162 ) is well documented. The meaning or nature behind the associations is for the moment less clear but it seems inescapable that in all cases such associations - whilst no doubt materially and functionally exploited - also retained a symbolism fixed within a wider cosmological set of beliefs.

\section{Conclusion}


At around the middle of the $3^{\text {rd }}$ millennium BC and possibly as early as 2800 BC a succession of henge monuments was constructed on a low chalk spur on the eastern side of a river valley in which there appears to have been little evidence for significant settlement activity. This appears to suggest a movement away from more intensive activity elsewhere on Cranborne Chase (to the north and west of the site), with the establishment of a new ceremonial and religious complex. It is unknown if the complex was focussed on the dead from its inception but its location and likely interaction with topographical features may have been articulated to a contemporary cosmogony in which the living and the dead were reconciled, from its beginnings. The pace of the development of the complex is unknown but the form of the monuments might suggest that a 'precinct' of ceremonial structures grew up located close to two important natural features - the River Allen and a doline field, both of which may have held cosmological significance to the attendant community. The construction of monuments commenced with new forms of earthwork enclosures that appear to retain characteristics from established building traditions. Within this earlier group of formative henges a large round barrow was constructed which surely further reflects the funerary associations of the complex, that would ultimately herald the establishment of an extensive barrow cemetery.

The river Allen itself may well have formed an important component within the belief system of the local community, acting both as a conduit that linked further burial grounds focussing on the location of other doline fields and possibly as a territorial boundary that separated landscapes of the living and the dead. The presence in these subsidiary burial grounds of further funerary structures could be seen to reflect the growth of a funereal landscape borne out of an ancestry linked to the traditional leanings of a cosmology rooted in the $4^{\text {th }}$ millennium - but subject to new and emerging social and religious ideas coincident with the introduction of a Beaker presence in the locality. That this extended complex would grow and develop with the periodic insertion of monuments both large and small is of course to be expected. The changes could equally however be reflective of a dynamic within society that finds physical and spiritual expression in the continual re-development and investment in a territorial homeland that provided focus for local communities for a thousand years.

\section{Acknowledgements}

Thanks to Professor Mark Maltby for commenting upon the structure and content of this paper and to Harry Manley for preparing Figures 1 and 6. I would also like to thank the two anonymous reviewers for their valued comments on an earlier draft of this paper. Any remaining mistakes of fact or judgement are, of course my own. This paper is a revised and expanded version of a lecture presented at a conference entitled The last great monuments: ceremonial complexes of the 3rd millennium B.C. held at the British Museum in November 2013.

\section{References}

Allen, M.J. 2000: Soils, pollen and lots of snails. In M.Green. A Landscape Revealed: 10000 years on a chalkland farm. 36-49. Stroud. Tempus 
Allen, M.J. 2007: Land use and landscape development: the molluscan evidence -the South Circle at Knowlton. In C. French, H. Lewis, M.J. Allen, M. Green, R. Scaife \& J. Gardiner (eds) Prehistoric landscape development and human impact in the upper Allen valley, Cranborne Chase, Dorset: 176-186. (McDonald Institute Monographs) Cambridge: McDonald Institute for Archaeological Research.

Atkinson, R. 1951: The henge monuments of Great Btitain. In R.Atkinson, C.M. Piggott and N.K.Sandars, Excavations at Dorchester, Oxon. 81-107,Oxford: Ashmolean Museum. Barber, M, Winton, H, Stoertz, C, Carpenter, E and Martin, L. 2010: The Brood of Silbury? A Remote Look at Some Other Sizeable Wessex Mounds. In J. Leary, T, Darvill and D.Field (eds) Round Mounds and Monumentality in the British Neolithic and Beyond, 153-173. Neolithic Studies Group Seminar Papers 10. Oxford: Oxbow.

Barclay, G.J. \& Russell-White, C.J. (eds) 1993: Excavations in the ceremonial complex of the fourth to second millennium BC at Balfarg/Balbirnie, Glenrothes, Fife. Proceedings of the Society of Antiquaries Scotland 123: 43-210.

Barclay, A., Gray, M \& Lambrick, G. 1995: Exacavations at the Devil's Quiots, Stanton Harcourt, Oxfordshire, 1972-3 and 1988. Oxford. Oxford Archaeological Unit (Thames Valley Landscapes: the Windrush Valley Volume 3).

Barrett, J. 1994: Fragments from Antiquity: An Archaeology of Social Life in Britain, 29001200 BC. Oxford: Blackwell.

Barrett, J., Bradley, R and Green, M. 1999: Landscape, Monuments and Society: The prehistory of Cranborne Chase. Cambridge University Press.

Bradley, R. 2000: An Archaeology of Natural Places.London and New York: Routledge.

Burrow, S. 2010: The Formative Henge: Speculations Drawn from the Circular Traditions of Wales and Adjacent Counties. In (eds) J. Leary, T. Darvill and D. Field. Round Mounds and Monumentality in the British Neolithic and Beyond. Neolithic Studies Group Seminar Papers 10. Oxford. Oxbow: 182-96.

Clare, T., 1986: Towards a reappraisal of henge monuments, Proceedings of the Prehistoric Society, 52, 281-316.

Darvill, T. 1997: Ever Increasing Circles: The Sacred Geographies of Stonehenge and its Landscape, Proceedings of the British Academy. 92: 167-202

Darvill, T. 2006: Stonehenge: The biography of a landscape. Stroud. Tempus.

Darvill, T. 2010: Prehistoric Britain (2nd ed). London \& New York. Routledge.

Evans, C. 1988: Acts of enclosure: a consideration of concentrically-organised causewayed enclosures, in J.C. Barrett and I. A. Kinnes (eds) The Archaeology of Context in the Neolithic and Bronze Age: Recent trends. Sheffield.

Field, N. 1962: Discoveries at the Knowlton Circles, Woodlands, Dorset. Proceedings of the Dorset Natural History and Archaeological Association 84: 117-24

French, C., Lewis, H., Allen, M.J., Green, M., Scaife, R. \& Gardiner, J (eds) Prehistoric landscape development and human impact in the upper Allen valley, Cranborne Chase, Dorset: 176-186. (McDonald Institute Monographs) Cambridge: McDonald Institute for Archaeological Research.

Gale. J., 2012: Late Neolithic Henge Monuments as Foci for Evolving Funerary Landscapes: Knowlton Henge Complex and the Barrow Cemeteries of the Allen Valley, Dorset, 
UK - A Case Study. In W. Bebermeier, R. Hebenstreit, E. Kaiser and J. Krause (eds) Landscape Archaeology. Proceedings of the International Conference held in Berlin $6^{\text {th }}-8^{\text {th }}$ June 2102. eTopoi Journal for Ancient Studies Special Volume 3: 161-7.

Gale, J., Laver, J and Randall, C. 2006: Excavations at High Lea Farm, Hinton Martell, Dorset: An Interim Report on Fieldwork Undertaken during 2002-5. Proceedings of the Dorset Natural History and Archaeological Society 127:

Gale, J., Hewitt, I and Russell, M. 2008: Excavations at High Lea Farm, Hinton Martell, Dorset: An Interim Report on Fieldwork Undertaken During 2006-7. Proceedings of the Dorset Natural History and Archaeological Society 129: 104-14

Green, M. 2000: A Landscape Revealed: 10,000 Years on a Chalkland Farm. Stroud. Tempus.

Harding, A. 2000: Henge monuments and landscape features in northern England: monumentality and nature. In A. Ritchie (ed) Neolithic Orkney in its European Context: 267-75. (McDonald Institute Monographs) Cambridge: McDonald Institute for Archaeological Research.

Harding, A.F. and Lee, G.E. 1987: Henge Monuments and Related Sites of Great Britain. Oxford. British Archaeological Reports (British Series) 175

Harding, J. 2000: Later Neolithic Ceremonial Centres, Ritual and Pilgrimage: the Monument Complex of Thornbouough, North Yorkshire. In A. Ritchie (ed) Neolithic Orkney in its European Context: 31-46 (McDonald Institute Monographs) Cambridge:

McDonald Institute for Archaeological Research.

Harding, J. 2003: Henge Monuments of the British Isles. Stroud: Tempus

Houlder, C. 1968: The henge monuments at Llandegai. Antiquity XLII (166): 216-21

Healy, F. 1997: Site 3. Flagstones. In R.J.C. Smith, F. Healy, M.J. Allen, E.L. Morris, I. Barnes and P.J.Woodward. Excavations along the Route of the Dorchester By-pass, Dorset, 1986-8. Wessex Archaeology Report No.11. Salisbury: Wessex Archaeology: 27-48.

Lewis, J and Mullin, D. 2011: New Excavations at Priddy Circle I, Mendip Hills, Somerset. Proceedings of the University of Bristol Spelaeological Society 25(2): 133-163

Lynch, F and Musson, C., 2001: A prehistoric and early medieval complex at Llandegai, near Bangor, North Wales: Excavations directed by C.H. Houlder 1966-67. Archaeologia Cambrensis 150: 17-143

Parker Pearson, M., 2007: The Stonehenge Riverside Project: excavations at the east entrance of Durrington Walls. In M.Larson and M. Parker Pearson (eds) From Stonehenge to the Baltic: cultural diversity in the third millennium BC. Oxford: BAR (International Series) 1692, 125-44.

Parker Pearson, M., 2012: Stonehenge: exploring the greatest Stone Age mystery. London: Simon and Schuster.

Parker Pearson, M \& Ramilisonina, R., 1998: Stonehenge for the ancestors: the stones pass on the message. Antiquity, 72, 308-26

Richards, C. 1996: Henges and Water: Towards an Elemental Understanding of Monumentality and Landscape in Late Neolithic Britain, Journal of Material Culture 1 (3): 313-336. 
Smith, R.J.C., Healy, F., Allen, M.J., Morris, E.L., Barnes, I and Woodward. 1997: Excavations Along the Route of the Dorchester By-pass, Dorset, 1986-8. Wessex Archaeology Report No. 11. Salisbury: Wessex Archaeology.

Stoertz, C. 2007: Aerial photographic survey of Knowlton Circles, in C. French, H. Lewis, M.J. Allen, M. Green, R. Scaife \& J. Gardiner (eds) Prehistoric landscape development and human impact in the upper Allen valley, Cranborne Chase, Dorset: 40-43. (McDonald Institute Monographs) Cambridge: McDonald Institute for Archaeological Research: 40-3.

Tilley, C. 1994: A Phenomenology of Landscape: Places, Paths and Monuments. Oxford: Berg.

Tilley, C. 1999: Metaphor and Material Culture. Oxford: Blackwell

Whitley, J. 2002: Too many ancestors. Antiquity 76, 119-26

Whittle, A., Atkinson, R.J.C., Chambers, R. \& Thomas, N. 1992: Excavations in the Neolithic and Bronze Age Complex at Dorchester on Thames, Oxfordshire, 19471952 and 1981. Proceedings of the Prehistoric Society 58, 143-202.

Woodward, A. 2000: British Barrows: A Matter of Life and Death. Stroud: Tempus

\section{Notes on Contributor}

John Gale is a Senior Lecturer in Archaeology at Bournemouth Archaeology where he has taught and researched for 25 years. He is currently bringing to completion research into the prehistoric complex at Knowlton, part of his long-term interest in the Later Neolithic and Bronze periods in southern England. Contact: jgale@bmth.ac.uk 